\title{
How to Hire and Manage Residential Contractors ${ }^{1}$
}

\author{
Randall A. Cantrell ${ }^{2}$
}

\section{Quick Facts}

- A home typically is purchased after passing an inspection conducted by a trained professional (Ruppert, Fentriss, \& Lee, 2008).

- Passing a home inspection shows the home complies with building codes and is safe for occupancy (International Code Council, 2011).

- In 2011, more than 12,000 housing units were certified by the LEED for Homes program and approximately 6,000 by the ICC-700 standard (U.S. Green Building Council, 2011; NAHB Research Center, 2011).

- The Florida Green Building Coalition has certified more than 5,400 homes in Florida (Florida Green Building Coalition, 2013).

\section{Terms to Help You Get Started}

- Single-family residence: Detached residential building suited for tenancy by one family unit (Florida Building Code, 2010).

- Multi-family residence: Any residential dwelling unit attached to another such unit by a common wall, ceiling, or floor such as a duplex, townhouse, condominium or similar unit, regardless of ownership (Florida Building Code, 2010).

- Residential contractor: A contractor whose services are limited to construction, remodeling, repair, or improvement of one-family, two-family, or three-family residences not more than two stories and the "accessory use structures" in connection with these buildings. An accessory use structure would be a garage, guest house, garden shed, or other outbuilding (Florida Department of Business and Professional Regulation, 2013).

- Scope of services: A document defining the precise work for which a contractor is offering a price quote.

- Change order: Any alteration or amendment to construction after the scope of services has been finalized.

- "As-built" contract: A document defining a scope of services such that an addition will match the existing structure in all agreed-upon manners of construction.

- Call-backs: Any craftsmanship and/or materials requiring rework after the construction job has been completed.

- Green building: Describes a set of policies and practices to ensure that buildings are built and used in ways that are as environmentally responsible and resource-efficient as possible from construction to demolition (Allen \& Lano, 2008).

- USGBC: U.S. Green Building Council.

- LEED for Homes: Leadership in Energy and Environmental Design for Homes, a residential green building program established by the USGBC.

- NAHB ICC-700: One of the more prominent green building programs in the United States. Known as ICC700 and developed by the National Association of Home Builders (NAHB).

- Florida Green Building Coalition: A nonprofit Florida corporation dedicated to improving the built environment (Florida Green Building Coalition, 2013).

1. This document is FCS3318, one of a series of Department of Family, Youth and Community Sciences, UF/IFAS Extension. Original publication date: September 2013. Visit the EDIS website at http://edis.ifas.ufl.edu.

2. Randall A. Cantrell, assistant professor, Department of Family, Youth and Community Sciences; UF/IFAS Extension, Gainesville, FL 32611.

This material was prepared with the support of the University of Florida. However, any opinions, findings, conclusions, or recommendations expressed herein are those of the author(s) and do not necessarily reflect the views of the University of Florida. 


\section{Keywords}

Homebuilding, Remodeling, Contractor Selection, Residential Green Building Programs

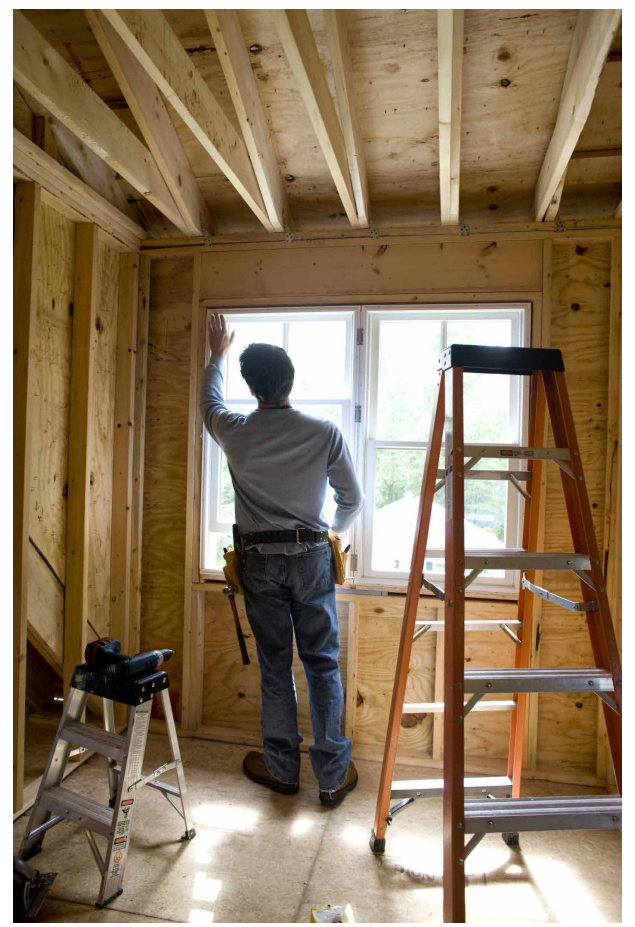

Figure 1. You need to carefully select a contractor to work on your home, so make sure you understand the hiring process and agree on specific details before signing a contract. Credits: (c) David Sacks (Lifesize)

\section{Why You Should Select a Contractor Carefully}

The following story shows why it is important to choose a contractor carefully and to understand what you should look for when hiring one. The rest of this publication describes what you need to know about hiring a residential contractor, such as understanding the contract process, finding a contractor, determining a payment schedule, knowing the differences between types of contractors, and having questions to ask before hiring a contractor. This publication is part of a series called "Builder, Remodeler, and Home Buyer Knowledge" to help Florida residents understand what they need to know before buying, building, or remodeling a home. The rest of the series is available at http://edis.ifas.ufl.edu/ topic_series_builder_remodeler_home_buyer.

A homeowner decided to add a sunroom and contacted the contractor who built the home. After agreeing on the final design and price, they entered into a contract. Although the contract was an "as-built" contract, the builder was delayed in completing the addition. However, the contract did not include a penalty clause for work not completed on time. The builder became ill, and the project was delayed indefinitely. Enough work was completed for the house to pass final inspection for occupancy, but some exterior details had not been completed according to the agreement. The parties agreed the homeowner would pay $50 \%$ of the total cost when the job began and 50\% when the job was completed.

After the builder regained health and verified the home passed the final inspection, the contractor billed the homeowner for the remaining unpaid balance. The homeowner did not pay the full amount and instead subtracted the amount quoted by another contractor to complete the remaining exterior details. However, the contractor insisted the job was complete on passing the final inspection and sent overdue bills (including interest) to the homeowner. The homeowner contacted an attorney who helped draft a cease-and-desist order to resolve the matter. The homeowner did not hear from the contractor again, but the work was not completed until years later when the home was listed for sale. The cost to prepare the home for sale was ultimately increased by a cost of about $\$ 1,000$ in uncompleted work.

\section{Why You Should Understand the Contractor Price Quote Process}

When hiring a contractor, make sure the contractor is licensed in the state to do business and is bonded. The contractor should also possess workers' compensation insurance and provide a precise scope of services for the price quote being offered. Using a properly licensed contractor is not a guarantee of a successful project, but it provides the owner with remedies if problems arise. Before you sign a contract, check the contractor's current active status as a licensed contractor. You can do this by obtaining the contractor's individual license number and verifying it with the Florida Department of Business and Professional Regulation (DPBR). Visit the DBPR's website (http:// www.myfloridalicense.com/dbpr/index.html) and click on "Verify a License" or call its customer contact center (850-487-1395).

Residential contractors are only permitted to provide services corresponding to the license(s) they possess in Florida, but may provide multiple services in the areas where they are licensed. Subcontractors employed by a contractor typically are the contractor's responsibility and 
evidence of their work-related documents should be on file before starting any work with the contractor (for more information, see http://www.myfloridalicense.com/dbpr/ pro/cilb/codes.html).

Contractors use many types of contracts, and most of them are written to protect the contractor, not the homeowner. Before you sign any contract, carefully read it and address any questions to the contractor. Also, add any clarifications to the contract to avoid misunderstandings.

Typically, a homeowner should solicit price quotes from three different contractors to see which offers the best value. Be careful not to misinterpret value as just the lowest price. One contractor may offer a different scope of services for accomplishing the job. Make sure you understand the fine details to determine if the price quotes are for the exact same amount of labor and type of materials or if one contractor offers differences from other contractors. Also, any project that does not secure building permits from the local building permit office automatically puts the homeowner at risk. This is important because homes need to be inspected before they are listed for sale. If a home inspector determines that any part of the home does not meet the minimum standards required by the international building code (or local building code), then the home must be brought up to code at a complete cost to the homeowner before it can be sold.

\section{Finding a Contractor and Determining Contractor Financial Stability}

A contractor usually has completed multiple jobs within driving distance of your home. As a potential client, you can request a list of those jobs and contacts. You may not be able to visit these contacts' homes, but often these contacts will at least talk to you on the phone to discuss the contractor's work. Some contractors offer referral payments to homeowners who allow potential clients to visit, usually only if the visitors hire the contractor to do the pending job. Further, a credible contractor should be willing to certify revenues in reserve and/or offer business loan arrangements to cover the cost of any anticipated work agreed on in the scope of services.

\section{Determining Compensation, Payment Schedule, Breech, and Warranty in a Contract}

When negotiating a contract, you must agree on specific details in writing regarding payment. These details should include how much will be paid in advance (to buy materials, etc.), how much will be paid in "draws" (periodic payments during the actual construction process), and how much will be paid on completion. The "draws" or amounts paid to the contractor should be closely related to the percentage of work completed at the date of payment. This can be accomplished by a payment schedule in the contract based on stages of completion (such as concrete slab poured/placed, roof dry-in, etc.) or based on a percentage of completion for each set period (such as biweekly or monthly). Also, a substantial final payment, payable only after the certificate of occupancy (if applicable) has been issued and all corrective work has been completed, can encourage the contractor to complete the project to the owner's satisfaction. Both parties should agree on a clear definition of what constitutes "completion" of the job.

Any change orders that occur during the construction process should be handled separately from the original contract. All inspection requests must be the contractor's responsibility, and make sure the contract specifically includes what constitutes contract breach (e.g., how many times the contractor can fail inspection before being terminated). Further, once the contractor has completed the job, a warranty must be in place that outlines how "call-backs" are handled and what period of time they are honored. This must include materials and labor costs incurred after the job is complete.

\section{Construction Liens}

Be aware that under Florida law individuals who provide labor or materials to make improvements to your property, such as for the construction or remodeling of a home, are granted "lien" rights for unpaid items. The law concerning construction liens is found in Title XL, Chapter 713 of the Florida Statutes. These lien rights are not limited to your contractor and extend to most subcontractors, material suppliers, and laborers, even if you (as the owner) have not contracted directly with them (these are called "non-privity" lienors). As a result, you may be liable to pay for labor or materials, even though you already paid your contractor for the same work. In other words, you many end up paying twice for the same thing! There are a number of documents vital to the operation of the lien law. The forms specified for 
this law include the following: Notice of Commencement, Notice to Owner, and Claim of Lien (for more information, see: http://www.floridabar.org/tfb/TFBConsum.nsf/0a92a6 dc28e76ae58525700a005d0d53/15ec22b45ab4d753852572ff 006b43c1?OpenDocument).

\section{Questions to Ask Contractors}

The following list provides some basic questions a homeowner should ask before hiring a contractor:

- What is the average time your company takes to respond to a client after receiving a call?

- What is the average turnaround time for a verbal, written, or in-person estimated scope of work and budget once your company has contacted a potential client?

- Do you train your staff to provide high-quality customer service? If so, please provide any helpful documents explaining your company's customer service policy related to your mission, goals, objectives, and/or principles.

\section{Information Contractors Should Provide to Homeowners}

The following list includes information homeowners can ask a contractor regarding any persons working for them who will enter onto the homeowner's property, including employees or subcontractors. You have the right to know the following information about employees and subcontractors:

- Name

- Title

- Qualifications

- Experience

- Years of service with current company

- Years of experience in relevant industry/trade

- Relevant professional certifications

\section{Understanding Differences}

\section{Between Types of Builders}

The residential construction sector has innovative builders who erect homes according to nationally recognized green standards (Cantrell, 2012). In doing so, they attempt to increase home occupants' awareness and desire for new building products and materials (Koebel et al., 2003). Homebuyers need to understand what it means to buy a home certified by a green building program (GBP). Some builders understand better than others the benefits associated with building to such standards. Alternatively, some builders may try to convince homeowners that they are building to green standards without the need for certification through a GBP. In these cases, the builder may try to sell what sounds like a green construction project when in reality it is not a true "green" construction project. If a contractor attempts to sell you a "green" job without certifying it through a GBP, then request that each green item be discussed while referring to a GBP manual. This will assist you in understanding how closely the contractor aligns each work item to actual GPB criteria.

\section{Summary}

If you are looking for a contractor for either home building or remodeling, ask difficult questions before you enter into a contract. This way you and the contractor have a clear understanding of the other's expectations. Before signing a contract and beginning a project is the best time to thank contractors for their consideration and time, rather than risk entering into an unfortunate working relationship that could require legal intervention. Contractors understand potential clients, and they will inform you if they do not want to accept a contract with you. This negotiation period should not be taken personally by either party and should only develop into a business relationship that exists during the period of hire and warranty outlined in the contract.

\section{Resources}

- For more information on Florida's Asbestos Licensing terms and codes, see http://www.myfloridalicense.com/ dbpr/pro/asbest/index.html.

- For more information on Florida's Home Inspectors Licensing Program, see http://www.myfloridalicense. com/dbpr/pro/homein/index.html.

- For more information on Florida's Mold Remediation Licensing terms and codes, see http://www.myfloridalicense.com/dbpr/pro/mold/index.html.

- For more information on EPA certification, see http:// epa.gov/lead/pubs/traincert.htm. 


\section{References}

Allen, E., \& Lano, J. (2008). Fundamentals of building construction: Materials and methods. Hoboken, NJ: John Wiley \& Sons, Inc.

Cantrell, R. (2012). Comparisons between green homebuilders and traditional homebuilders. Journal of Forest Products Business Research.

Florida Building Code. (2010). Energy conservation, Chapter 2, Section 202. Retrieved from http://www.ecodes. biz/ecodes_support/free_resources/2010Florida/Energy/

PDFs/Chapter\%202\%20-\%20Definitions.pdf

Florida Department of Business and Professional Regulation. (2013). Construction industry licensing board. Retrieved from http://www.myfloridalicense.com/dbpr/pro/ cilb/codes.html

Florida Green Building Coalition. (2013). Press releases. Retrieved from http://www.floridagreenbuilding.org/ press-releases (2013). About us. Re-

trieved from http://www.floridagreenbuilding.org/about-us International Code Council. (2011). About ICC. Retrieved from http://www.iccsafe.org/ABOUTICC/Pages/default. aspx

Koebel, T., Papadakis, M., Hudson, E., \& Cavell, M. (2003). The diffusion of innovation in the residential building industry. Prepared for the U.S. Department of Housing and Urban Development, Office of Policy Development and Research. Washington, DC: U.S. Department of Housing and Urban Development.

NAHB Research Center (2011). NAHB Green. Retrieved from http://www.nahbgreen.org/Certification/report.aspx

Ruppert, K. C., Fentriss, A. C., \& Lee, H. J. (2008). Energy efficient homes: Home inspections. FCS3279. Gainesville: University of Florida Institute of Food and Agricultural Sciences. http://edis.ifas.ufl.edu/fy1048.

U.S. Green Building Council. (2011). LEED for Homes. Retrieved from http://www.usgbc.org/DisplayPage. aspx?CMSPageID $=147$ 